\title{
Integument cell differentiation in dandelions (Taraxacum, Asteraceae, Lactuceae) with special attention paid to plasmodesmata
}

\author{
Bartosz J. Plachno ${ }^{1}$ • Ewa Kurczyńska ${ }^{2} \cdot$ Piotr Świątek $^{3}$ \\ Received: 26 April 2015 / Accepted: 2 October 2015 / Published online: 10 October 2015 \\ (C) The Author(s) 2015. This article is published with open access at Springerlink.com
}

\begin{abstract}
The aim of the paper is to determine what happens with plasmodesmata when mucilage is secreted into the periplasmic space in plant cells. Ultrastructural analysis of the periendothelial zone mucilage cells was performed on examples of the ovule tissues of several sexual and apomictic Taraxacum species. The cytoplasm of the periendothelial zone cells was dense, filled by numerous organelles and profiles of rough endoplasmic reticulum and active Golgi dictyosomes with vesicles that contained fibrillar material. At the beginning of the differentiation process of the periendothelial zone, the cells were connected by primary plasmodesmata. However, during the differentiation and the thickening of the cell walls (mucilage deposition), the plasmodesmata become elongated and associated with cytoplasmic bridges. The cytoplasmic bridges may connect the protoplast to the plasmodesmata through the mucilage layers in order to maintain cell-to-cell communication during the differentiation of the periendothelial zone cells.
\end{abstract}

Keywords Apomixis $\cdot$ Asteraceae $\cdot$ Cell wall $\cdot$ Integument $\cdot$ Mucilage $\cdot$ Ovule $\cdot$ Plasmodesmata $\cdot$ Ultrastructure

Handling Editor: Manfred Heinlein

Bartosz J. Płachno

bartosz.plachno@uj.edu.pl

1 Department of Plant Cytology and Embryology, Jagiellonian University in Kraków, 9 Gronostajowa St., 30-387 Kraków, Poland

2 Department of Cell Biology, University of Silesia, 28 Jagiellońska St., 40-032 Katowice, Poland

3 Department of Animal Histology and Embryology, University of Silesia, 9 Bankowa St., 40-007 Katowice, Poland

\section{Introduction}

In some members of the Asteraceae family, there is a specific cell differentiation in the integument. The part of the internal integument behind the endothelium and the region near the antipodal cells form a zone that is called the periendothelial zone and that is also called the nutritive integument tissue or pseudochalaza (Cooper and Brink 1949; Engell and Petersen 1977; Pandey et al. 1978; Musiał et al. 2013). Depending on the changes in this integument zone, three types of ovules were proposed in Asteraceae: "Taraxacum", "Galinsoga" and "Ratibida". "Taraxacum" type cells have very swollen walls with a spongy structure (Kolczyk et al. 2014). Some characteristics of these cells such as a reduction in protoplast size and thickening of the cell wall are similar to mucilage cells. According to Pandey et al. (1978), the cells of periendothelial zone undergo gelatinisation in Youngia japonica. Moreover, a liquefaction of the integument cells was observed in Hieracium by Koltunow et al. (1998). Musiał et al. (2013) claimed that these cells undergo progressive degeneration in Taraxacum, which is probably by programmed cell death (PCD).

In plants, mucilage may play various physiological roles: carbohydrate storage (Pimienta-Barrios and Nobel 1998), catching prey in carnivorous plants with adhesive traps (e.g., Juniper et al. 1989; Król et al. 2012), water storage and drought tolerance (Clifford et al. 2002), frost tolerance (Lipp et al. 1994) and host-pathogen interactions (Davis et al. 1986). The role of mucilage cells in ensuring seed viability and germination (Western et al. 2000; Yang et al. 2010; Kreitschitz 2012) may apply to Taraxacum ovules and young seeds.

In recent years, it has been postulated that the symplasmic communication that occurs due to the existence of plasmodesmata in plants plays an important role in the regulation of cell differentiation (Brunkard et al. 2013; Burch-Smith et al. 2011; 
Marzec and Kurczynska 2014), since it was shown that plasmodesmata provide a passageway not only for nutrients but also for various types of signal molecules including proteins, transcriptional factors and RNAs (Gursanscky et al. 2011; Hyun et al. 2011; Jang 2014). The correlation between symplasmic communication and cell differentiation was shown for different developmental processes such as zygotic and somatic embryogenesis (Kozieradzka-Kiszkurno et al. 2011; Kozieradzka-Kiszkurno and Płachno 2012), androgenesis (Wrobel et al. 2011), root cell differentiation (BenitezAlfonso et al. 2014; Marzec et al. 2013), shoot apical meristem organisation and transition from a vegetative to generative state of development (Paul et al. 2014) or the development of cambial cells (Ehlers and van Bel 2010; Fuchs et al. 2010). Plasmodesmata are dynamic "intercellular bridges" whose permeability to different molecules changes according to the state of development or the influence of different signals, both external and internal (Kragler 2013; Marzec and Kurczynska 2014; Ueki and Citovsky 2011). Changes in plasmodesmata permeability are correlated with their modifications such as elongation, branching, fusion or even loss of appressed ER (Kollmann R. Glockamnn C 1999). Such modifications were described, for example, in the case of the Strasburger cell in Abutilon nectar trichomes or in the parenchyma sheet of maize leaves and during the development of wheat caryopses (Glockmann and Kollmann 1996). In the mucilage cells of dicotyledons, the secreted material is deposited between the plasmalemma and the cell wall (Bakker and Baas 1993). The mucilage accumulates in the periplasmic space, thus pressing the protoplast away from the cell wall, and, according to Baker and Baas (1993), the mucilage covers the plasmodesmata, which leads to the loss of plasmodesmata function and cell-to-cell communication.

However, our knowledge about plasmodesmata modification and symplasmic transport in such a cell type is still insufficient. The question is what happens when material is secreted into the periplasmic space in Taraxacum: (1) Do plasmodesmata become sealed (occluded by wall material) or degraded or (2) Do they undergo other modifications?

To the best of our knowledge, we describe the differentiation of plasmodesmatal connections in the mucilage cells of angiosperms in detail for the first time. The paper presents the unusual structure of the cell wall and the differentiation of plasmodesmatal connections in the periendothelial zone of Taraxacum. Taraxacum is the model taxon for apomixis and its integument tissue was shown to influence apomictic development (Tucker et al. 2012). Thus, our observations on the differentiation of the integument tissue in this taxon may contribute to our understanding of sexual and apomictic seed development under the influence of the integument.

\section{Material and methods}

\section{Plant material}

We studied and compared the changes in ovule tissue among several sexual and apomictic Taraxacum species. Sexual species were represented by two diploid species-Taraxacum tenuifolium (Hoppe \& Hornsch.) Koch (T. sect. Palustria) and Taraxacum linearisquameum Soest [T. sect. Taraxacum; syn $T$. sect. Ruderalia (Kirschner and Štěpánek 2011)]. The apomictic sample was represented by various apomictic taxa from the $T$. sect. Taraxacum (T. officinale agg. clone SA-B from Palacký University, Olomouc, Czech Republic and specimens that were collected in Kraków-Podgórze, Poland) and Taraxacum brandenburgicum Hudziok (sect. Palustria). We also used Taraxacum pieninicum Pawł. (section Erythrocarpa) from the Botanical Garden of the Maria $\mathrm{Cu}-$ rie-Skłodowska University, Lublin collection. Studies were carried out on buds and flowers before and during anthesis.

Irrespective of the time of harvest before or during anthesis, the flowers of the diploid species contained ovules with mature embryo sacs of the Polygonum type. The flowers of the apomictic species harvested before anthesis contained the mature embryo sac whereas the flowers harvested during anthesis already contained embryo and endosperm, as previously observed (Płachno et al. 2014; Płachno et al. 2015). Analysis was performed on at least three different samples from each species. Sixteen sections were analysed in TEM (about ten mucilage cells per section were analysed in TEM for each ovule and ten other typical integumentary cells were also analysed for comparison). About 160 walls with plasmodesmata of mucilage cells were analysed. The figures that are presented are representative of all of the species that were analysed.

Vouchers of the taxa that were examined were deposited in the herbarium of Jagiellonian University in Kraków (KRA), with the exception of T. officinale s.l. (clone SA-B), which was deposited in the herbarium of the Department of Botany, Palacký University, Olomouc, Czech Republic.

\section{Light and electron microscopy studies}

The preparation of the samples for TEM (transmission electron microscopy) followed the procedure described by Płachno and Świątek (2009) and Płachno (2011). Briefly, ovaries were fixed in $2.5 \%$ formaldehyde and $2.5 \%$ glutaraldehyde in a $0.05 \mathrm{M}$ cacodylate buffer ( $\mathrm{pH} 7.0$ ) for 2 days. The material was postfixed in $1 \% \mathrm{OsO}_{4}$ in a cacodylate buffer for $24 \mathrm{~h}$ at $\sim 4{ }^{\circ} \mathrm{C}$, rinsed in the same buffer, treated with $1 \%$ uranyl acetate in distilled water for $1 \mathrm{~h}$, dehydrated with an acetone series and embedded in an Epoxy Embedding Medium Kit (Fluka) or in Spurr's resin. Semithin sections were stained using aqueous methylene blue with azure II for general 
histology (Humphrey and Pittman 1974) for 1-2 min (MB/ AII) and examined using an Olympus BX60 microscope. The periodic acid-Schiff (PAS) reaction was used to visualise the total carbohydrates of insoluble polysaccharides (Wędzony 1996). The presence of mucilage substances was analysed using neutral red according to the method described by O’Brien and McCully (1981).

Ultrathin sections were cut on a Leica Ultracut UCT ultramicrotome. After contrasting with uranyl acetate and lead citrate, the sections were examined using a Hitachi H500 electron microscope at $75 \mathrm{kV}$ in the Faculty of Biology and Environmental Protection, University of Silesia in Katowice and a Jeol JEM 100 SX; JEOL, Tokyo, Japan, at $80 \mathrm{kV}$ in the Department of Cell Biology and Imaging, Institute of Zoology, Jagiellonian University in Kraków.

\section{Results}

In samples showing mature embryo sacs (in apomicts in closed flowers; see Fig. 1a, in sexual dandelions during anthesis), the cells of periendothelial zone are still alive, despite the reduction in protoplast size (Fig. 1b, c). At this stage, the cytoplasm of the periendothelial zone cells is dense and is filled by numerous organelles. The protoplast has an irregular shape with numerous plasmalemma invaginations. Cortical microtubules are clearly visible near the plasmalemma (Fig. 1c). There are numerous profiles of rough endoplasmic reticulum and dictyosomes with numerous vesicles that are present mostly in association with the newly formed cell walls (Figs. 1c and 2a). The dictyosome vesicles are large and contain fibrillar material (Fig. 2a). Exocytosis of these vesicles was observed (Fig. 2b). The nuclei and nucleoli of the periendothelial zone cells are large (Fig. 1c). Staining with methylene blue with azure II allows different layers in the wall of periendothelial zone cells to be distinguished (Fig. 1b). In addition, the layers are clearly visible in TEM (Fig. 2a). In the vicinity of the plasmalemma, there was an almost amorphous, electron-translucent layer that had fibrillar, electron-dense components (Fig. 2b). Moreover, a thick layer of an amorphous wall matrix with dense fibrillar material in a reticulate arrangement (Fig. 2a, b) and the primary cell wall, which was present before the deposition of the mucilage material, were distinguished (arrows, Fig. 2b). The thickening of the cell wall apparently occurs through the apposition of secreted material. Staining with neutral red and with methylene blue with azure II showed that the first two layers had a mucilage character. A middle lamella was seen as an electron-dense layer, especially between the periendothelial zone cells and other integument cell types (Fig. 2c).

Analysis of the modified wall ultrastructure showed the presence of electron-dense structures that traverse the mucilage layers and that may connect the cytoplasm to the

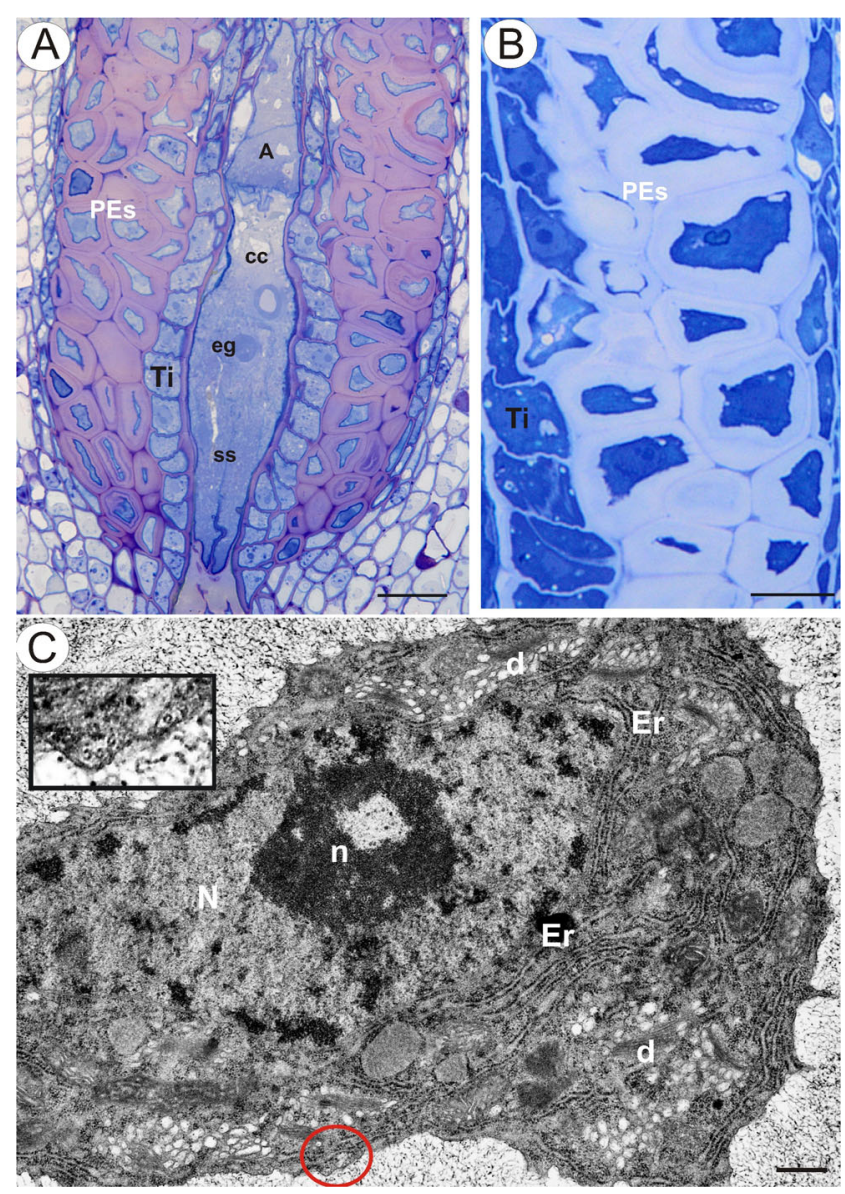

Fig 1 a T. officinale s.l. (clone SA-B). Semithin section through an ovule with embryo sac showing the structure of periendothelial zone cells $(P E s)$; egg cell (eg), central cell $(c c)$, synergids (ss), antipodes $(A)$ and integumental tapetum (Ti), bar $=20 \mu \mathrm{m}$. b $T$. officinale s.l. (clone SA-B). Semithin section through the integument showing periendothelial zone cells, $b a r=10 \mu \mathrm{m}$. c Sexual dandelion $T$. tenuifolium (ovule from flower during anthesis). Ultrastructure of periendothelial zone cells; dictyosomes $(d)$, rough endoplasmic reticulum $(E r)$, nucleus $(N)$, nucleolus $(n)$ and framed part shows cortical microtubules near plasmalemma (red circle), bar $=0.5 \mu \mathrm{m}$

plasmodesmata (Figs. 2c, 3a, b, 4a, b and 5a). These structures appeared to be cytoplasmic bridges (Fig. 4a, b) with clearly visible plasmalemma, microtubules and vesicles. Both their dimensions and the presence of microtubules inside these structures clearly indicate that these bridges are indeed cytoplasmic protrusions and do not represent extensions of the plasmodesmata themselves. However, typical plasmodesmata were present close to the primary wall in this modified wall (Fig. 3c). In some cases, these plasmodesmata traverse the wall perpendicular to the plane of the section (Fig. 3c). Their structure is typical with clearly visible plasmalemma and a desmotubule (Fig. 3c). There is a gradient of mucilage deposition that is dependent on the cell position (Figs. $3 a$ and $5 b-$ d). Periendothelial zone cells start to differentiate at the young ovule stage (when the young embryo sac occurs), and these cells have typical plasmodesmata in their cell walls. In fully 


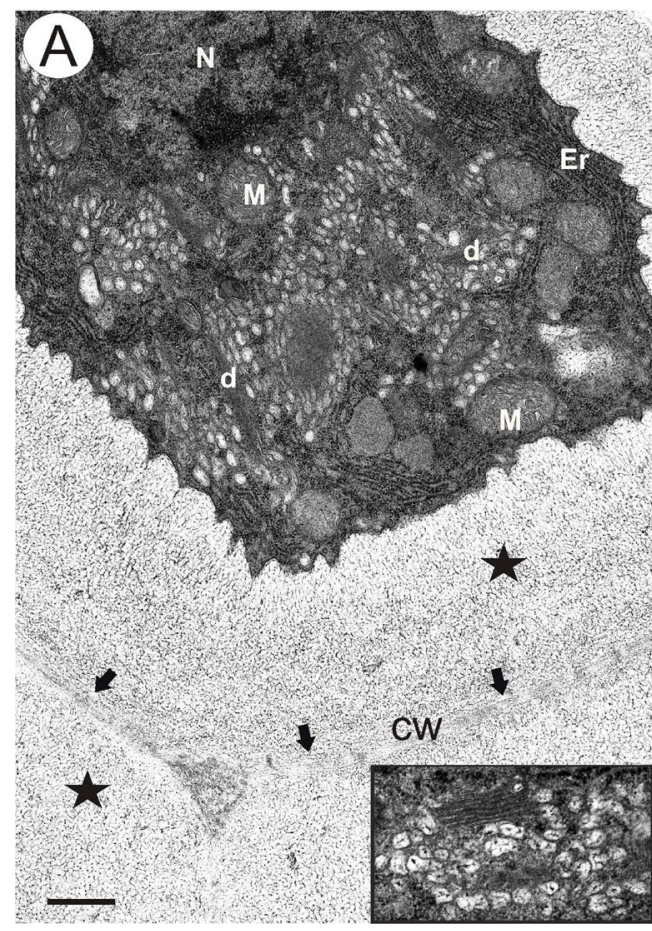

Fig 2 Ultrastructure of periendothelial zone cells in Taraxacum. a T. officinale s.l. (clone SA-B, ovules from flowers just before anthesis) electron micrograph showing the general ultrastructure of a periendothelial zone cell; mitochondrion $(M)$, dictyosomes $(d)$, rough endoplasmic reticulum $(E r)$, nucleus $(N)$, primary cell wall (cw, arrows) and cell wall layer with a reticulate appearance of wall material (star), bar $=0.6 \mu \mathrm{m}$; framed part shows T. tenuifolium dictyosome with numerous vesicles that contain fibril material. b The T. officinale s.l.

developed mucilage periendothelial cells, mucilage material was deposited between the primary cell wall and plasmalemma on all sides of the cells (Fig. 2a). The cytoplasmic bridges only occurred in these kinds of cells. It appears likely that the cytoplasmic bridges allow the cells to maintain intercellular connectivity despite the formation of the large mucilage layers that spatially separate the protoplasts from the cell walls. One hundred percent of the plasmodesmata that were observed in these cells were connected with cytoplasmic bridges. Non-mucilage integumentary cells had typical plasmodesmata without cytoplasmic bridges (Fig. 5b, c). When a mucilage cell borders with a non-mucilage cell, the elongation of the plasmodesmata and the formation of cytoplasmic bridges occurred only from the side of the mucilage cell (Figs. 3a and 5a).

\section{Discussion}

Only a few papers have been published that discussed results concerning the ultrastructure of the integumentary cells of Asteraceae (Newcomb 1973; Figueiredo et al. 2006; Musiał et al. 2013; Kolczyk et al. 2014). In the present paper, we show that the periendothelial cells in Taraxacum are rich in profiles of rough endoplasmic

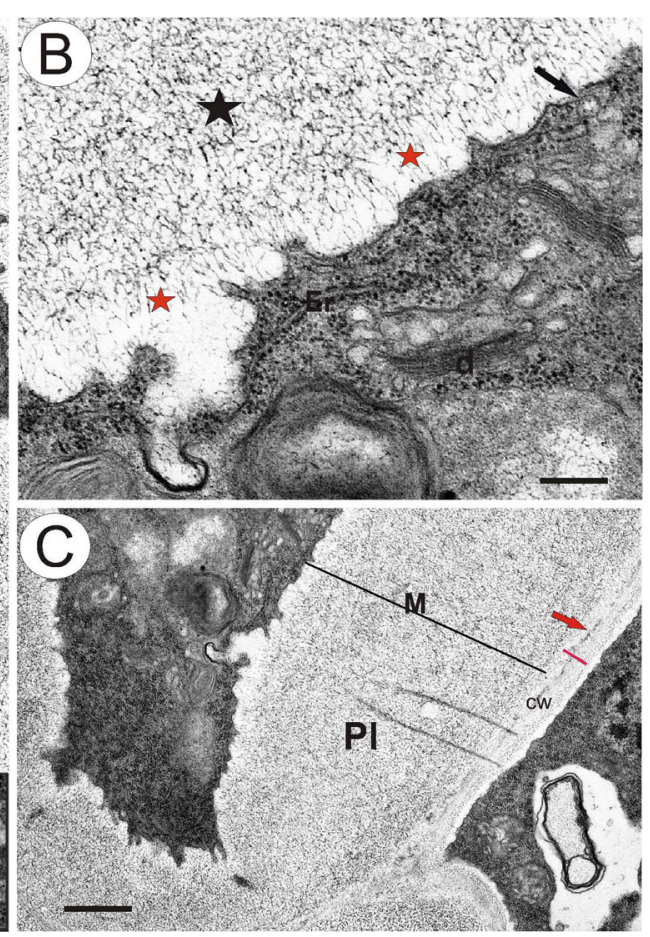

(clone SA-B) part of a periendothelial zone cell, note the lobed plasmalemma, cortical microtubules and exocytose of the dictyosome vesicle (arrow), dictyosome $(d)$, rough endoplasmic reticulum $(E r)$, amorphic layer of the cell wall (red star) and the cell wall layer with microfibrils (star), bar $=0.3 \mu \mathrm{m}$. c $T$. officinale s.l. (clone SA-B) plasmodesmata $(P l)$ between a periendothelial zone cell and parenchyma cell, reticulate mucilage material $(M)$, middle lamella (arrow) and primary cell wall (cw, red line), bar $=1 \mu \mathrm{m}$

reticulum and dictyosomes with numerous secretory vesicles. Our ultrastructural observations in Taraxacum are similar to the results that were obtained by Newcomb (1973) in Helianthus annus. Newcomb observed that sunflower periendothelial zone cells were completely filled with wall material. This wall in Taraxacum was previously described as a wall with an open spongy structure by Musiał et al. (2013). A similar observation was made in other Asteraceae that have a Taraxacum type of ovule such as Solidago, Chondilla, and Bellis (Kolczyk et al. 2014). However, based on our observations, we now know that this new "wall material" has a mucilage character. This was suggested by both the texture of the deposited wall material as well as the staining reaction of this material in the presence of methylene blue with azure II and neutral red. This result corresponds well with the high activity of Golgi apparatus (numerous secretory vesicles with mucilage material), which was observed in our study on Taraxacum and also, previously, in Helianthus (Newcomb 1973). Moreover, we observed fibrillar material, which structurally resembles the fibrillar material deposited within the wall, in the Golgi vesicles. The Golgi apparatus was described as the source of mucilage in many types of mucilage cells in members of 
Fig 3 Plasmodesmata and cytoplasmic bridges in the integument cells of $T$. officinale s.l. (clone SA-B, ovules from flowers just before anthesis) a Contact between a periendothelial zone cell and parenchyma cell, cytoplasmic bridges (white arrow), cytoplasmic connections (black arrow) in reticulate appearance mucilage material, plasmodesma in the primary cell wall (in red circle), middle lamella $(m)$ and primary wall (cw), bar $=0.25 \mu \mathrm{m}$. b

Longitudinal section though cytoplasmic connections (arrow) shown in $\mathbf{a}$, bar $=0.2 \mu \mathrm{m}$. $\mathbf{c}$ Transverse section through plasmodesmata in this modified wall close to the primary wall, bar $=0.1 \mu \mathrm{m}$
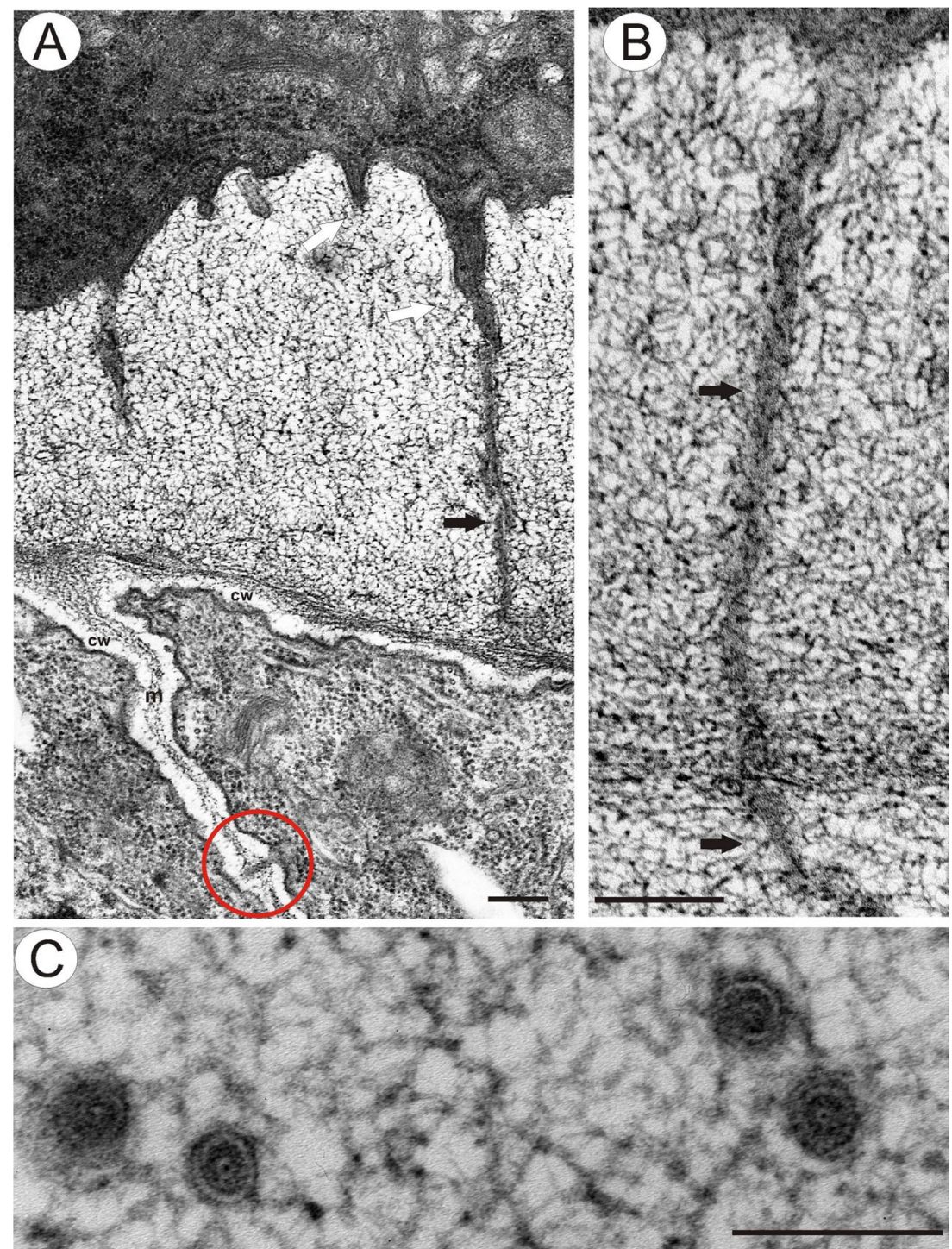

various families, e.g., Cactaceae, Droseraceae, Lauraceae and Malvaceae (Mollenhauer 1967; Outenreath and
Dauwalder 1982; Trachtenberg and Fahn 1981; Bakker and Baas 1993). However, in some rare cases, other
Fig 4 Cytoplasmic connections in the integument cells of T. officinale s.l. (clone SA-B, ovules from flowers just before anthesis) a, b Longitudinal section though cytoplasmic connections in the mucilage material (white arrow), modified wall - mucilage (black star), microtubules (red arrow), bar= $0.5 \mu \mathrm{m}$ and $\mathrm{bar}=0.2 \mu \mathrm{m}$
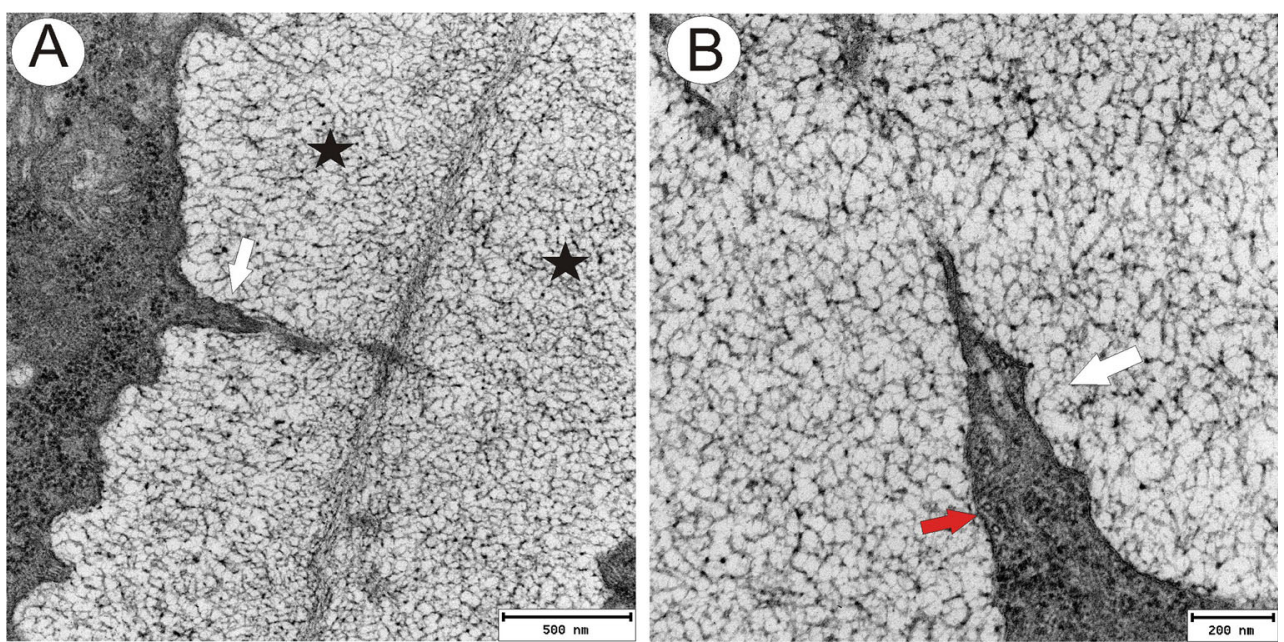


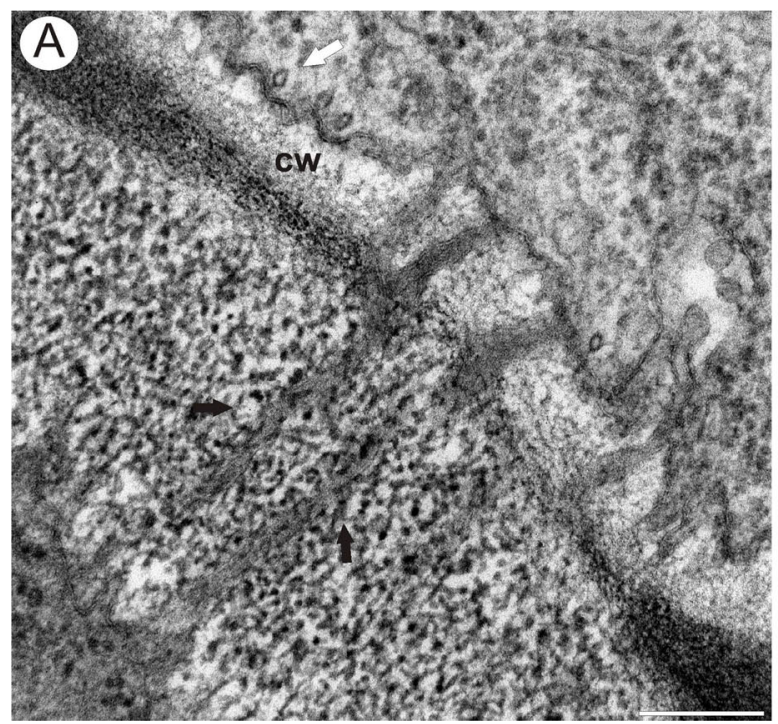

Fig. 5 Plasmodesmata in integument cells. a-d T. officinale s.l. (clone SA-B, ovules from flowers just before anthesis); a Longitudinal section though plasmodesmata in the mucilage material (black arrow), primary wall $(c w)$, microtubules (white arrow), bar $=0.2 \mu \mathrm{m}$. b Gradient of plasmodesmata modifications and mucilage deposition between different integument cells, typical plasmodesmata (red circle), slightly
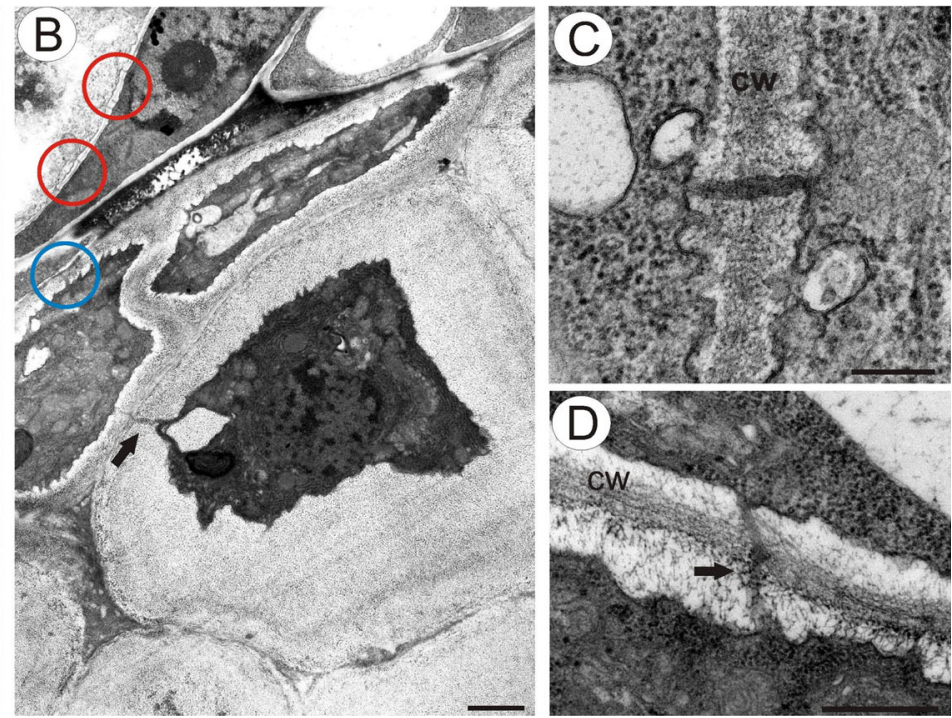

elongated plasmodesmata (blue circle), elongated plasmodesmata with a cytoplasmic connection in the mucilage layer (arrow), bar $=1.7 \mu \mathrm{m}$. c Typical plasmodesmata (similar ones are also shown in the red circle in (b)), primary wall ( $c w)$, bar $=0.2 \mu \mathrm{m}$. d Slightly elongated plasmodesma (black arrow) (similar ones are also shown in the blue circle in (b)), primary wall $(c w), b a r=0.5 \mu \mathrm{m}$ organelles are probably the source of mucilage as was proposed for Aloe (Trachtenberg 1984).

The integumentary mucilage cells of Taraxacum are similar in some characters to the mucilage cells of other dicotyledons in which mucilage material is deposited between the plasmalemma and the cell wall (Bakker and Baas 1993). However, the mucilage cells in these species are quite different than those that have been described in Araucaria angustifolia mesophyll (Mastroberti and de Araujo Mariath 2008). In the case of Araucaria, the secretion is deposited into a specialised cavity that is situated between the cytoplasm and the central vacuole (see Fig. 27 in Mastroberti and de Araujo Mariath 2008). However, like in Taraxacum, the mucilage structure in Cinnamomum (Bakker et al. 1991) or the gymnosperms Araucaria (Mastroberti and de Araujo Mariath 2008) showed a similar fibrillar or reticulate character. Thus, a Taraxacumlike mucilage occurs also in non-related taxa.

We observed that the periendothelial zone cells in Taraxacum begin to differentiate at the young ovule stage (when the young non-cellular embryo sac occurs). In Helianthus, this material deposition process begins during the early cellular embryo sac stage (Newcomb 1973). In Hieracium, the wall changes of the periendothelial zone cells start during the four-nucleate embryo sac stage (Koltunow et al. 1998).

Plasmodesmata undergo different modifications during cell differentiation (Jones 1976; Lucas and Wolf 1993). In the case of primary plasmodesmata, these modifications include elongation, branching or fusion of adjacent plasmodesmata (Kollmann R. Glockamnn C 1999). According to the definition, primary plasmodesmata are formed during cytokinesis. Primary plasmodesmata that undergo branching during the secondary apposition of wall material are called secondarily modified primary plasmodesmata. In contrast, secondary plasmodesmata are plasmodesmata that are formed across preexisting cell walls (Botha and Cross 2001). In the presented studies, it is shown that the analysed mucilage cells are connected by primary plasmodesmata with a single linear channel. As the wall grows in thickness, these plasmodesmata grow in length, without undergoing other detectable modifications (Fig. 3c). Occlusion or closing of plasmodesmata in mucilage cells was suggested by early studies (Bakker and Baas 1993). However, our observation that the plasmodesmata in mucilage cells are linked to the protoplast via cytoplasmic bridges suggests that they are functional. An elongation of the primary plasmodesmata that correlated with an increase of the wall thickness was described for the Strasburger cells of the needles of Metasequoia (Glockmann and Kollmann 1996). The cytoplasmic strands may be analogous to Hechtian strands. Both Hechtian strands and cytoplasmic bridges connect plasmodesmata with the cytoplasm - in the case of Hechtian strands across the space caused by plasmolysis (Oparka et al. 1994) and in the case of the structures described in this paper across a region of mucilage.

\section{The function and fate of integumentary mucilage cells}

It is believed that the periendothelial zone cells in Asteraceae nourish the embryo, thereby reducing the importance of the endosperm function (Koltunow et al. 1998; van Baarlen et al. 
1999; Musiał et al. 2013). However, we think that in addition to a nutritional role (which should be experimentally proven), the mucilage periendothelial zone cells may facilitate the regulation of hydration during the early stages of seed development. Moreover, the degradation of these cells forms the space that is needed for the growing embryo. Degradation of this tissue during embryogenesis in Taraxacum was recorded by Cooper and Brink (1949). Figueiredo et al. (2006) observed PCD in the periendothelial zone cells of Cynara; however, they interpreted these cells as having a nucellar origin.

When we interpret the results about ovules in Asteraceae (Kolczyk et al. 2014) in the light of our results, it seems that the mucilage cells are a common character in Asteraceae ovules and occur in species that have a high reproductive success (genera Taraxacum, Solidago, Chondilla, Bellis). Thus, the mucilage cells seem to be important for the physiology of ovules and young seeds. The functional significance of the observed cytoplasmic bridges remains to be shown. We suppose that for active mucilage production, symplasmic transport is required. In order to ensure the proper function of plasmodesmata in these specialised cells, cytoplasmic bridges are formed.

\section{Conclusion}

We show that specialised mucilage cells in the integument of developing Taraxacum seeds form cytoplasmic bridges to connect the cytoplasm with the plasmodesmata through mucilage layers. This suggests the importance of communication between these cells during seed development. However, further studies are needed to demonstrate that the cytoplasmic bridges are indeed required for intercellular communication in integument tissues.

\section{Future prospective}

The plasmodesmata and cell contacts that are described provide an attractive model to test cell-to-cell communication during cell differentiation. Future analyses should involve studies on symplasmic transport and fluorochrome distribution within and between the integumentary tissues. Moreover, the chemical composition of the mucilage and the wall of the integument cells in Taraxacum must be studied using immunolabelling methods.

Acknowledgments This study was funded by the National Science Centre, Poland. Contract grant number DEC-2013/09/B/NZ8/03308. We cordially thank both Dr. Luboš Majeský (Palacký University) and Dr. Jolanta Marciniuk (Siedlce University of Natural Sciences and Humanities) for kindly providing part of the plant material. We also thank our colleague Dr. Mykhaylo Chernetskyy (MCSU Botanical Garden in Lublin) for the Taraxacum pieninicum material. We also thank Dr. Olga Woźnicka for her expert technical help with Jeol JEM 100.

\section{Compliance with ethical standards}

Conflict of interest The authors declare that they have no competing interests.

Open Access This article is distributed under the terms of the Creative Commons Attribution 4.0 International License (http:// creativecommons.org/licenses/by/4.0/), which permits unrestricted use, distribution, and reproduction in any medium, provided you give appropriate credit to the original author(s) and the source, provide a link to the Creative Commons license, and indicate if changes were made.

\section{References}

Bakker ME, Baas P (1993) Cell walls in oil and mucilage cell. Acta Bot Neerl 42(2):133-139

Bakker ME, Gerritsen AF, Van Der Schaaf JP (1991) Development of oil and mucilage cells in Cinnamomum burmanni. An ultrastructural study. Acta Bot Neerl 40:339-356

Benitez-Alfonso Y, Faulkner C, Pendle A, Miyashima S, Helariutta Y, Maule A (2014) Symplastic intercellular connectivity regulates lateral root patterning. Develop Cell 26:136-147

Botha CEJ, Cross RHM (2001) Regulation within the supracellular highway - plasmodesmata are the key. South African J Bot 67:1-9

Brunkard JO, Runkel AM, Zambryski PC (2013) Plasmodesmata dynamics are coordinated by intracellular signaling pathways. Curr Opin Plant Biol 16:614-620

Burch-Smith TM, Stonebloom S, Xu M, Zambryski PC (2011) Plasmodesmata during development: re-examination of the importance of primary, secondary and branched plasmodesmata structure versus function. Protoplasma 248:61-74

Clifford SC, Arndt SK, Popp M, Jones HG (2002) Mucilages and polysaccharides in Ziziphus species (Rhamnaceae): localization, composition and physiological roles during drought-stress. J Exp Bot 53: $131-138$

Cooper DC, Brink RA (1949) The endosperm-embryo relationship in the autonomous apomict, Taraxacum officinale. Botanical Gazette 111: $139-152$

Davis KR, Darvill AG, Albersheim P, Dell A (1986) Host-pathogen interactions. XXIX. Oligogalacturonides released from sodium polypectate by endopolygalacturonic acid lyase are elicitors of phytoalexines in soybean. Plant Physiol 80:568-577

Ehlers K, van Bel AJE (2010) Dynamics of plasmodesmal connectivity in successive interfaces of the cambial zone. Planta 231:371-385

Engell K, Petersen GB (1977) Integumentary and endothelial cells of Bellis perennis. Bot Tidsskrift 71:237-244

Figueiredo R, Duarte P, Pereira S, Pissarra J (2006) The embryo sac of Cynara cardunculus: ultrastructure of the development and localisation of the aspartic proteinase cardosin B. Sex Plant Reprod 19:93-101

Fuchs M, Ehlers K, Will T, van Bel AJE (2010) Immunolocalization indicates plasmodesmal trafficking of storage proteins during cambial reactivation in Populus nigra. Ann Bot 106:385-394

Glockmann C, Kollmann R (1996) Structure and development of cell connections in the phloem of Metasequoia glyptostroboides needles. I. Ultrastructural aspects of modified primary plasmodesmata in Strasburger cells. Protoplasma 193:191-203

Gursanscky NR, Searle IR, Carroll BJ (2011) Mobile microRNAs hit the target. Traffic 12:1475-1482

Hyun TK, Uddin MN, Rim Y, Kim J-Y (2011) Cell-to-cell trafficking of RNA and RNA silencing through plasmodesmata. Protoplasma 248: $101-116$ 
Humphrey CD, Pittman FE (1974) A simple methylene blue-azure IIbasic fuchsin stain for poxy-embedded tissue sections. Stain Technol 49:9-14

Jang G, Lee J-Y (2014) Intercellular trafficking of transcription factors in the vascular tissue patterning. Physiol Plant. doi:10.1111/ppl.12140

Jones MGK (1976) The origin and development of plasmodesmata. In: Gunning BES, Robards AW (eds) Intercellular communication in plants: studies on plasmodesmata. Springer, Berlin, pp 81-105

Juniper BE, Robins RJ, Joel JM (1989) The carnivorous plants. Academic, London

Kirschner J, Štěpánek J (2011) Typification of Leontodon taraxacum L. (Taraxacum officinale FH Wigg.) and the generic name Taraxacum: a review and a new typification proposal. Taxon 60:216-220

Kolczyk J, Stolarczyk P, Płachno BJ (2014) Comparative anatomy of ovules in Galinsoga, Solidago and Ratibida (Asteraceae). Acta Biol Cracov Ser Bot 56(2):115-125

Kollmann R. Glockamnn C (1999) Multimorphology and nomenclature of plasmodesmata in higher plants. In: van Bell A JE, van Kesteren WJP (eds). Plasmodesmata. Structure, function, role in cell communication. 149-172

Koltunow AM, Johnson SD, Bicknell RA (1998) Sexual and apomictic development in Hieracium. Sex Plant Reprod 11:213-230

Kozieradzka-Kiszkurno M, Płachno BJ (2012) Are there symplastic connections between the endosperm and embryo in some angiosperms? - a lesson from the Crassulaceae family. Protoplasma 249:1081-1089

Kozieradzka-Kiszkurno M, Płachno BJ, Bohdanowicz J (2011) Are unusual plasmodesmata in the embryo-suspensor restricted to species from the genus Sedum among Crassulaceae? Flora 206:684-690. doi:10.1016/j.flora.2010.11.017

Kragler F (2013) Plasmodesmata: intercellular tunnels facilitating transport of macromolecules in plants. Cell Tissue Res 352:49-58

Kreitschitz A (2012) Mucilage formation in selected taxa of the genus Artemisia L. (Asteraceae, Anthemideae). Seed Sci Res 22:177-189

Król E, Płachno BJ, Adamec L, Stolarz M, Dziubińska H, Trębacz K (2012) Quite a few reasons for calling carnivores 'the most wonderful plants in the world'. Ann Bot 109:47-64. doi:10.1093/aob/ mer249

Lipp CC, Goldstein G, Meinzer FC, Niemczura W (1994) Freezing tolerance and avoidance in high-elevation Hawaiian plants. Plant, Cell Environ 17:1035-1044

Lucas WJ, Wolf S (1993) Plasmodesmata: the intercellular maize plants are induced by adjacent mesophyll cells. Nature organelles of green plants. Trends Cell Biol 3:308-315

Marzec M, Kurczynska E (2014) Importance of symplasmic communication in cell differentiation. Plant Sig \& Beh 9:e27931; PMID: 24476959; http://dx.doi.org/10.4161/psb.27931tt

Marzec M, Muszynska A, Melzer M, Sas-Nowosielska H, Kurczynska EU (2013) Increased symplasmic permeability in barley root epidermal cells correlates with defects in root hair development. Plant Biol. doi:10.1111/plb.12066

Mastroberti AA, de Araujo Mariath JE (2008) Development of mucilage cells of Araucaria angustifolia (Araucariaceae). Protoplasma 232: 233-245

Mollenhauer HH (1967) The fine structure of mucilage secreting cells of Hibiscus esculentus. Protoplasma 63:353-362

Musiał K, Płachno BJ, Świątek P, Marciniuk J (2013) Anatomy of ovary and ovule in dandelions (Taraxacum, Asteraceae). Protoplasma 250: $715-722$
Newcomb W (1973) The development of the embryo sac of sunflower Helianthus annuus before fertilization. Can J Bot 51:863-878

O'Brien TP, McCully ME (1981) The study of plant structure: principles and selected methods. Melbourne: Termarcarphy Pty, 1981

Oparka KJ, Prior DAM, Crawford JW (1994) Behaviour of plasma membrane, cortical ER, and plasmodesmata during plasmolysis of onion epidermal cells. Plant, Cell Environ 17:163-171

Outenreath R, Dauwalder M (1982) Ultrastructural and radioautographic studies of the digestive gland cells of Drosera capensis: I. Development and mucilage secretion. J Ultra Mol Str Res 80:71-88

Pandey AK, Singh RP, Chopra S (1978) Development and structure of seeds and fruits in Compositae-Cichorieae. Phytomorphology 28: 198-206

Paul LK, Rinne PLH, van der Schoot C (2014) Shoot meristems of deciduous woody perennials: self-organization and morphogenetic transitions. Curr Opin Plant Biol 17:86-95

Pimienta-Barrios E, Nobel PS (1998) Vegetative, reproductive and physiological adaptations to aridity of pitayo (Stenocereus queretaroensis, Cactaceae). Econ Bot 52:401-411

Płachno BJ (2011) Female germ unit in Genlisea and Utricularia, with remarks about the evolution of the extra-ovular female gametophyte in members of Lentibulariaceae. Protoplasma 248:391-404

Płachno BJ, Światek P (2009) Functional anatomy of the ovule in Genlisea with remarks on ovule evolution in Lentibulariaceae. Protoplasma 236:39-48

Płachno BJ, Musiał K, Światek P, Tuleja M, Marciniuk J, GrabowskaJoachimiak A (2014) Synergids and filiform apparatus in the sexual and apomictic dandelions from section Palustria (Taraxacum, Asteraceae). Protoplasma 251:211-217

Płachno BJ, Świątek P, Kozierdzka-Kiszkurno M, Majeský L, Marciniuk J, Stolarczyk P (2015) Are obligatory apomicts invested in the pollen tube transmitting tissue? Comparison of the micropyle ultrastructure between sexual and apomictic dandelions (Asteraceae, Lactuceae). Protoplasma. doi:10.1007/s00709-015-0765-x

Trachtenberg S (1984) Cytochemical and morphological evidence for the involvement of the plasma membrane and plastids in mucilage secretion in Aloe arborescens. Ann Bot 53:227-236

Trachtenberg S, Fahn A (1981) The mucilage cells of Opuntia ficusindica (L.) Mill.- development, ultrastructure and mucilage secretion. Bot Gaz 142:206-213

Tucker MR, Okada T, Johnson SD, Takaiwa F, Koltunov AMG (2012) Sporophytic ovule tissues modulate the initiation and progression of apomixis in Hieracium. J Exp Bot 63:3229-3241

Ueki S, Citovsky V (2011) To gate, or not to gate: regulatory mechanisms for intercellular protein transport and virus movement in plants. Mol Plant 4:782-793

Van Baarlen P, Verduijn M, Van Dijk PJ (1999) What can we learn from natural apomicts? Trends Plant Sci 4:43-44

Wędzony M (1996) Fluorescence microscopy for botanists (in Polish). Dept. Plant Physiology Monographs 5. Kraków, Poland, p 128

Western TL, Debra JS, Haughn GW (2000) Differentiation of mucilage secretory cells of the Arabidopsis seed coat. Plant Physiol 122:345 355

Wrobel J, Barlow PW, Gorka K, Nabialkowska D, Kurczynska EU (2011) Histology and symplasmic tracer distribution during development of barley androgenic embryos. Planta 233:873-881

Yang X, Dong M, Huang Z (2010) Role of mucilage in the germination of Artemisia sphaerocephala (Asteraceae) achenes exposed to osmotic stress and salinity. Plant Physiol Biochem 48:131-135 